\title{
FH2 Domain-Containing Protein 1
}

National Cancer Institute

\section{Source}

National Cancer Institute. FH2 Domain-Containing Protein 1. NCI Thesaurus. Code C114606.

FH2 domain-containing protein $1(1143 \mathrm{aa}, \sim 125 \mathrm{kDa})$ is encoded by the human FHDC1 gene. This protein may play a role in both cell shape and microtubule polymerization. 